\title{
Penggunaan Kombinasi Ekstrak Akar Saluang Belum (Lavanga sarmentosa) dengan Akar Kuning (Arcangelisia flava Merr) terhadap Daya Hambat Bakteri Aeromonas hydrophila Secara In Vitro
}

\author{
Maryani $^{1}$, Kartika Bungas ${ }^{2}$, Hasan Anwar $^{3}$ \\ 1,2,3Prodi Budidaya Perairan, Jurusan Perikanan , Fakultas Pertanian UPR \\ *Correspondence email: maryani@ fish.upr.ac.id
}

\begin{abstract}
Abstrak. Penelitian tentang kandungan senyawa tanaman Akar Saluang Belum (Lavanga sarmentosa) dan tanaman Akar Kuning ((Arcangelisia flava Merr) yang memiliki efek antibakteri perlu dibuktikan, Untuk itu penelitian ini bertujuan mengetahui pengaruh kombinasi Akar Saluang Belum (Lavanga sarmentosa) dengan Akar Kuning (Arcangelisia flava Merr) terhadap daya hambat bakteri Aeromonas hydrophila Secara In Vitro. Metode yang digunakan dalam penelitian ini adalah Rancangan Acak Lengkap (RAL) dengan 6 (enam) perlakuan dan 3 (tiga) kali ulangan yaitu perlakuan $\mathrm{A}=25 \mathrm{gr} / 150 \mathrm{ml}$ akuades, perlakuan $\mathrm{B}=35$ $\mathrm{gr} / 150 \mathrm{ml}$ akuades, perlakuan $\mathrm{C}=45 \mathrm{gr} / 150 \mathrm{ml}$ akuades, perlakuan $\mathrm{D}=55 \mathrm{gr} / 150 \mathrm{ml}$ akuades, perlakuan $\mathrm{E}=500 \mathrm{mg}$ kloromfenikol/150 ml akuades, dan perlakuan $\mathrm{F}=$ kontrol negatif yaitu hanya menggunakan campuran akuades $150 \mathrm{ml}$. Hasil penelitian ini menunjukkan bahwa kombinasi ekstrak Akar Saluang Belum (Lavanga sarmentosa) dengan Akar Kuning (Arcangelisia flava Merr) mampu menghambat pertumbuhan bakteri Aeromonas hydrophila karena memiliki efek antibakteri, hal ini dapat dilihat dari hasil rata-rata zona (daya hambat) pada setiap perlakuan yaitu zona bening tertinggi terdapat pada perlakuan D $55 \mathrm{gr} / 150 \mathrm{ml}$ dengan nilai zona bening rata-rata $15 \mathrm{~mm}$ dan hasil zona bening terendah yaitu perlakuan A $25 \mathrm{gr} / 150$ $\mathrm{ml}$ dengan nilai zona bening rata-rata $11 \mathrm{~mm}$.
\end{abstract}

Kata kunci: Aeromonas hydrophila; Akar Saluang Belum; Akar Kuning; Antibakteri.

Abstract. Saluang Belum Root (Lavanga sarmentosa) and Yellow Root ((Arcangelisia flava) Merr) plants that have antibacterial effects need to be proven, for this research this program uses Saluang Belum Root (Lavanga sarmentosa) with Yellow Root (Arcangelisia flava) Merr) against bacterial inhibition. Aeromonas hydrophila by In Vitro. The method used in this study was a Completely Randomized Design (CRD) with 6 (six) settings and 3 (three) replications related to the aid of A=25 gr $/ 150 \mathrm{ml}$ distilled water, treatment $B=35 \mathrm{gr} / 150 \mathrm{ml}$ distilled water, $C$ treatment $=45 \mathrm{gr} / 150 \mathrm{ml}$ distilled water, treatment $D=55 \mathrm{gr} /$ $150 \mathrm{ml}$ distilled water, handling $E=500 \mathrm{mg}$ chloromphenicol $/ 150 \mathrm{ml}$ distilled water, and treatment $F=$ negative control only using the use of $150 \mathrm{ml}$ distilled water. The results of this study indicate a combination of Saluang Belum Root Root (Lavanga sarmentosa) with Yellow Root (Arcangelisia flava Merr) which is able to inhibit the growth of My Aeromonas hydrophila bacteria because it has an antibacterial effect, this can be seen from the results of the zone average (inhibitory power) on each The treatment is the highest clear zone according to the $D 55 \mathrm{gr} / 150 \mathrm{ml}$ treatment with an average clear zone of $15 \mathrm{~mm}$ and the lowest clear zone yield is A $25 \mathrm{gr} / 150 \mathrm{ml}$ approval with an average clear zone value of $11 \mathrm{~mm}$.

Keywords: Aeromonas hydrophila; Root of Saluang Not yet; Yellow Root; Antibacterial.

\section{PENDAHULUAN}

Akar Saluang Belum (Lavanga sarmentosa) merupakan salah satu tanaman herbal yang memiliki manfaat sebagai obat tradisonal di Kalimantan Tengah. Obat tradisional banyak digunakan masyarakat karena hasilnya yang paten meskipun khasiatnya dapat dirasakan dalam jangka waktu cukup lama (Meira, 2014). Akar Kuning (Arcangelisia flava Merr) yang telah lama dikenal secara empiris oleh masyarakat dayak Kalimantan Tengah sebagai tanaman herbal alami untuk mengobati penyakit kuning. Senyawa yang terdapat pada Akar Kuning (Arcangelisia flava Merr) yaitu alkaloid, saponin, terpenoid dan flavonoid (Maryani et al., 2013). Sedangkan tanaman Akar Saluang Belum (Lavanga sarmentosa) mengandung senyawa metabolit sekunder yakni yaitu saponin dan tanin yang memiliki efek antibakteri dan antioksidan. Pengujian efek antibakteri Akar Saluang Belum (Lavanga sarmentosa) terhadap bakteri Staphyloccus aureus terdapat zona hambat 26,7 mm pada konsetrasi $0,5 \%, 21,6 \mathrm{~mm}$ pada konsentrasi $1 \%$ dan 20,5 $\mathrm{mm}$ pada konsetrasi 5\% (Qamariah, 2018)..

Dalam kegiatan budidaya ikan terdapat masalah yang dianggap sering menjadi penghambat budidaya ikan terbesar adalah munculnya penyakit. Karena serangan penyakit yang disebabkan oleh serangan bakteri Aeromonas hydrophila dapat merugikan secara ekonomis, bahkan menggagalkan hasil panen (Kordi, 2004). Aeromonas hydrophila. merupakan bakteri yang berasal dari lingkungan perairan dan dapat menyebabkan berbagai penyakit pada ikan. Genus Aeromonas memiliki sifat gram negatif yang mampu memfermentasikan beberapa glukosa, fruktosa, maltosa, dan trehalosa. Aeromonas hydrophila telah diidentifikasi sebagai pathogen dari berbagai jenis ikan air tawar, penyebab penyakit Motile Aeromonas septisemia (MAS) di seluruh dunia. MAS ditandai oleh lesi kecil permukaan yang mengarah pada lepasnya sisik, 
pendarahan lokal terutama insang dan anus, abses dan perut kembung (Rezeky, 2016).

Pengobatan pada Ikan yang terserang bakteri biasanya dilakukan dengan menggunakan antibiotik, namun penggunaan antibiotik ternyata dapat menimbulkan efek samping bagi patogen itu sendiri maupun terhadap ikan yang dipelihara. Pemberian antibiotik secara terus menerus dapat menyebabkan organisme patogen menjadi resisten, sehingga penggunaan antimikroba menjadi tidak efektif. Selain itu, residu dari antibiotik tersebut dapat mencemari lingkungan perairan yang mengakibatkan kualitas air menjadi turun (Retnawati, 2008). Berkaitan dengan permasalahan tersebut, perlu adanya alternatif bahan obat yang lebih aman yang dapat digunakan dalam pengendalian penyakit ikan. Salah satu alternatifnya adalah dengan menggunakan tumbuhan obat tradisional yang bersifat antibakteri.

Penelitian yang mengarah untuk khasiat penyembuhan penyakit ikan yang disebabkan oleh bakteri yang diuji secara ilmiah dari bahan Kombinasi Akar Saluang Belum (Lavanga sarmentosa) dengan Akar Kuning (Arcangelisia flava Merr) sampai saat ini masih belum dilakukan. Oleh karena itu perlu penelitian Kombinasi Akar Saluang Belum (Lavanga sarmentosa) dengan Akar Kuning (Arcangelisia flava Merr) untuk menghambat pertumbuhan bakteri Aeromonas hydrophila.

Penelitian ini bertujuan untuk mengetahui pengaruh Kombinasi Akar Saluang Belum (Lavanga sarmentosa) dengan Akar Kuning (Arcangelisia flava Merr) terhadap daya hambat bakteri Aeromonas hydrophila secara in vitro.

\section{METODE}

Penelitian ini dilaksanakan di Laboratorium Stasiun Karantina Ikan, Pengendalian Mutu dan Keamanan Hasil Perikanan Kelas I, Jl. Adonis Samad, Panarung, Pahandut, Kota Palangka Raya, Kalimantan Tengah.

\section{Alat dan Bahan}

Peralatan penelitian yang digunakan meliputi kertas saring, kertas label, aluminium foil dan paper disk. blender, tabung erlenmeyer, rotary evaporator, cawan petri, mikropipet, rak, tabung reaksi, corong, jarum ose, freeze dryer, laminar flow, autoclave, pembakar bunsen, penggaris, botol kaca dan vortex. Bahan penelitian yang digunakan adalah bakteri Bakteri ATCC $35654^{\mathrm{TM}}$ Aeromonas hydrophila, akar kuning, akar Saluang Belum, antibiotic kloramfenikol, Tripticase Soy Agar (TSA).

\section{Isolasi Bakteri Aeromonas hydrophila}

Bakteri Aeromonas hydrophila diperoleh dari Laboratorium Stasiun Karantina Ikan Kelas I Palangka Raya hasil dari uji Ikan Gabus Channa striata. Bakteri kemudian diawetkan pada media ATCC $35654^{\mathrm{TM}}$ untuk menjaga kualitas bakteri tersebut tetap dalam keadaan baik dan tentunya untuk menghindari dari kontaminasi mikroorganisme lain. Untuk memastikan bakteri yang tersimpan dalam media ATCC $35654^{\mathrm{TM}}$ adalah Aeromonas hydrophila maka dilakukan pemurnian dan uji biokimia terlebih dahulu, kemudian setelah itu dilakukan pembacaan hasil uji biokimia. Penggunaan virulensi bakteri Aeromonas hydrophila maka dilakukan penyuntikan pada sampel ikan Nila (Oreochromis niloticus). Selanjutnya diamati gejala yang terdapat pada ikan nila, ternyata kurang dari 24 jam ikan Nila tersebut telah menunjukkan gejala terserang bakteri Aeromonas hydrophila yaitu kulit ikan menjadi kasat dan timbul pendarahan, seluruh siripnya mulai rusak, setelah dilakukan pembedahan terihat pendarahan pada hati dan ginjal. Kemudian setelah pembedahan dilakukan isolasi bakteri yang diambil dari ginjal.

\section{Penumbuhan dan Pengenceran Bakteri Aeromonas hydrophila}

Kultur murni bakteri Aeromonas hydrophila dari media TSA disiapkan terlebih dahulu. Bakteri diambil satu ose untuk diencerkan ke dalam tabung reaksi yang berisi larutan Aquades steril dengan volume $9 \mathrm{ml}$ dan divortex untuk mendaptkan bakteri yang dibutuhkan dalam penelitian. Kekeruhan bakteri disamakan dengan kekeruhan Mc Farlan yang $10^{-5}$. Tabung reaksi yang berisi larutan Aquades steril dengan volume $9 \mathrm{ml}$ disiapkan. Bakteri dari kekeruhan $10^{-1}$ diambil $1 \mathrm{ml}$ kemudian dimasukkan ke dalam tabung reaksi yang berisi larutan Aquades steril dengan volume $9 \mathrm{ml}$ dan divortex untuk diencerkan kembali menjadi $10^{-2}$ dan diencerkan hingga didapatkan kekeruhan $10^{-5}$.

\section{Pembuatan Kombinasi Ekstrak Akar Saluang Belum (Lavanga sarmentosa) dan Akar Kuning (Arcangelisia flava Merr)}

Akar Saluang Belum (Lavanga sarmentosa) dan Akar Kuning (Arcangelisia flava Merr) dipotong-potong terlebih dahulu hingga berukuran kecil kemudian diblender menjadi serbuk. Kombinasi Akar Saluang Belum (Lavanga sarmentosa) dengan Akar Kuning (Arcangelisia flava Merr) ditimbang dengan jumlah sesuai perlakuan. Kemudian dicampur dengan akuades steril sebanyak $150 \mathrm{ml} /$ banyaknya perlakuan, dengan perbandingan 1:1, kemudian larutan kombinasi Akar Saluang Belum (Lavanga sarmentosa) dengan Akar Kuning (Arcangelisia flava Merr) tersebut dimasukkan ke dalam erlenmayer untuk disentrifus selama 10 menit pada $6000 \mathrm{rpm}$ untuk mendapatkan supernatan kombinasi akar Saluang Belum (Lavanga sarmentosa) dengan Akar Kuning (Arcangelisia flava Merr) yang kemudian dimasukkan ke dalam cawan petri steril yang berukuran sedang sebanyak $10 \mathrm{ml}$ dan didiamkan selama 24 jam (maserasi) di atas Laminary Air Flow (LAF) guna mengurangi uapan dan untuk memperoleh 
Maryani et al, Penggunaan Kombinasi Ekstrak Akar Saluang Belum (Lavanga sarmentosa) dengan Akar Kuning (Arcangelisia flava Merr) terhadap Daya Hambat Bakteri Aeromonas hydrophila Secara In Vitro

hasil ekstraksi yang diinginkan. Hasil ekstarksi dipengaruhi oleh beberapa faktor seperti bahan alami metode ekstraksi, ukuran partakel sampel, serta kondisi dan lamanya penyimpanan sampel (Maryani et al., 2013).

\section{Uji Antibakteri \\ Uji Cakram}

Sebanyak $1 \mathrm{ml}$ suspense bakteri (dari pengenceran $10^{-2}$ ) disebarkan secara merata pada media TSA dengan menggunakan ose. Masing-masing TSA diletakkan kertas cakram yang mengandung kombinasi ekstrak Akar Saluang Belum (Lavanga sarmentosa) dengan Akar Kuning (Arcangelisa flava Merr) dengan dosis 25 gr, 35 gr, 45 gr, dan 55 gr/150 ml, kloromfenikol (antibakteri) 500 gr sebagai kontrol positif dan kertas cakram yang mengandung akuades sebagai kontrol negatif. Kemudian cawan petri diinkubasi pada suhu $37^{\circ} \mathrm{C}$ selama 24 jam. Uji ini dilakukan dengan tiga kali pengulangan. Media diamati hasil dan diukur diameter zona bening yang terbentuk di sekitar kertas cakram dengan menggunakan penggaris (Rahman, 2008 dalam Ikrom et al., 2012).

\section{Parameter Penelitian}

Parameter yang diukur pada penelitian uji in vitro ada dua yaitu parameter utama dan parameter penunjang. Parameter utama dalam penelitian ini adalah hasil pengamatan yaitu hasil zona hambat bakteri dilakukan dengan cara mengukur dimeter zona bening sekitar kertas cakram pada berbagai konsentrasi, yaitu diameter minimum dan diameter maksimum yang dapat menghambat pertumbuhan bakteri. Zona bening merupakan petunjuk kepekaan bakteri terhadap bahan antibakteri yang digunakan sebagai bahan uji dan dinyatakan dengan diameter zona hambat. Sedangkan parameter penunjang adalah pengamatan hasil uji MIC (Minimum Inhibiting Concentration), hasil pengamatan yang dilihat adalah kekeruhan dan nilai absorbansi media.

\section{Rancangan dan Analisis Data}

Rancangan yang digunakan dalam penelitian ini menggunakan Rancangan Acak Lengkap (RAL). 6 X $3=$ 18; terdiri dari 6 perlakuan dan 3 kali ulangan. Perlakuan yang digunakan adalah penanaman bakteri Aeromonas hydrophila pada kombinasi ekstrak Akar Saluang Belum (Lavanga sarmentosa) dengan Akar Kuning (Arcangelisa flava Merr) dengan dosis yang berbeda sesuai kebutuhan dan pemberian antibiotik Kloromfenikol pada kontrol positif serta tanpa pemberian ekstrak akar Saluang Belum dan akar Kuning pada kontrol negatif (Akuades). Data yang diperoleh dalam penelitian ini akan dianalisa secara statistik menggunakan analisis ragam (ANOVA). Perlakuan yang akan diujikan dalam penelitian ini perlakuan A, B, $\mathrm{C}, \mathrm{D}, \mathrm{E}, \mathrm{F}$ dari masing-masing perlakuan dilakukan 3 kali ulangan.

$\mathrm{A}=25$ gr ekstrak Akar Saluang Belum dan Akar Kuning/150 ml Akuades

$\mathrm{B}=35$ gr ekstrak Akar Saluang Belum dan Akar Kuning/150 ml Akuades

$\mathrm{C}=45$ gr ekstrak Akar Saluang Belum dan Akar Kuning/150 ml Akuades

$\mathrm{D}=55$ gr ekstrak Akar Saluang Belum dan Akar Kuning/150 ml Akuades

$\mathrm{E}=500 \mathrm{mg}$ kloromfenikol (anti bakteri) - Kontrol positif/150 ml Akuades

$\mathrm{F}=$ Akuades, tidak diberikan ekstrak Akar Saluang Belum dan Akar Kuning -Kontrol negatif/150 ml Akuades

\section{HASIL DAN PEMBAHASAN Uji Cakram}

Dari hasil uji cakram yang dilakukan didapatkan hasil respon hambat yang disesuaikan menurut (Suryawiria, 2005) disajikan pada tabel 1.

Tabel 1. Hasil Pengamatan Zona Bening Setelah Pemberian Kombinasi Ekstrak Akar Saluang Belum (Lavanga sarmentosa) dengan Akar Kuning (Arcangelisa flava Merr) Terhadap Bakteri A. hydrophila

\begin{tabular}{|c|c|c|c|c|c|c|c|c|}
\hline \multirow[t]{2}{*}{ No. } & \multirow[t]{2}{*}{ Perlakuan } & \multicolumn{3}{|c|}{ Diameter Zona Bening (mm) } & \multirow[t]{2}{*}{ Total } & \multirow{2}{*}{$\begin{array}{c}\text { Rata- } \\
\text { rata }\end{array}$} & \multirow{2}{*}{$\begin{array}{c}\text { Respon Hambat } \\
\text { (Suryawiria, 2005) }\end{array}$} & \multirow{2}{*}{$\begin{array}{l}\text { Klasifikasi menurut } \\
\text { Suryawiria (2005) }\end{array}$} \\
\hline & & 1 & 2 & 3 & & & & \\
\hline 1 & $\mathrm{~A}$ & 11 & 10 & 13 & 34 & 11 & $10-19$ & Kuat \\
\hline 2 & B & 15 & 13 & 13 & 41 & 13 & $10-19$ & Kuat \\
\hline 3 & $\mathrm{C}$ & 16 & 14 & 14 & 44 & 14 & $10-19$ & Kuat \\
\hline 4 & $\mathrm{D}$ & 16 & 15 & 14 & 45 & 15 & $10-19$ & Kuat \\
\hline 5 & $\mathrm{E}$ & 40 & 42 & 43 & 125 & 41 & $>20$ & Sangat Kuat \\
\hline 6 & $\mathrm{~F}$ & 0 & 0 & 0 & 0 & 0 & 0 & - \\
\hline
\end{tabular}

Sumber: Data Primer diolah, 2019.

Berdasarkan hasil penelitian dari pengujian in vitro dengan metode cakram bahwa kombinasi ekstrak Akar Saluang Belum (Lavanga sarmentosa) dengan Akar Kuning (Arcangelisia flava Merr) mempunyai sifat antibakteri tergolong kuat dalam menghambat pertumbuhan bakteri Aeromonas hydrophila. Hal ini dapat dilihat dari terbentuknya zona bening (zona hambat) yaitu zona tidak tidak tumbuhnya bakteri di 
sekitar kertas cakram pada cawan petri. Berikut gambar hasil uji daya hambat bakteri Aeromonas hydrophila dengan uji cakram. Hasil Uji Cakram Kombinasi Ekstrak Akar Saluang Belum (Lavanga sarmentosa) dengan Akar Kuning (Arcangelisia flava Merr) disajikan pada Gambar. 1 berikut:

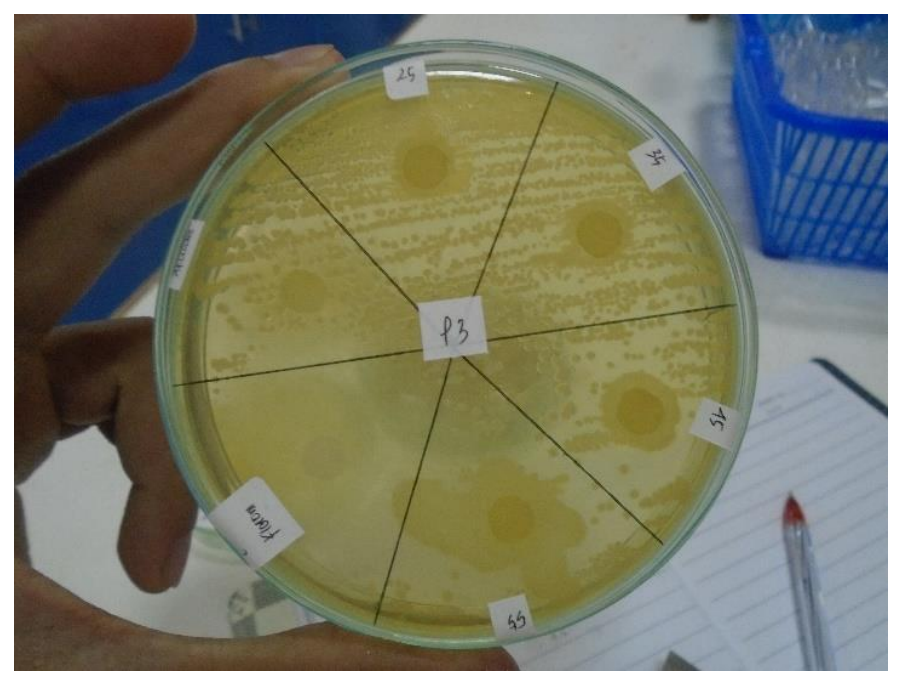

Gambar 1. Hasil Uji Cakram Kombinasi Ekstrak Akar Saluang Belum (L.sarmentosa dengan Akar Kuning (A. flava Merr)

Berdasarkan Tabel 1, mengenai hasil pengamatan zona bening setelah pemberian kombinasi ekstrak akar saluang belum (lavanga sarmentosa) dengan akar kuning (arcangelisa flava merr) terhadap bakteri $A$. hydrophila terhadap bakteri dengan uji cakram dapat ditentukan bahwa respon hambatan ekstrak pada perlakuan kontrol negatif tidak menunjukkan adanya zona. Namun, untuk setiap perlakuan pada konsentrasi $25 \mathrm{gr} / 150 \mathrm{ml}, 35 \mathrm{gr} / 150 \mathrm{ml}, 45 \mathrm{gr} / 150 \mathrm{ml}$ dan $55 \mathrm{gr} / 150$ $\mathrm{ml}$ memiliki respon hambat yang kuat. Sedangkan kontrol positif menggunakan kloramfenikol menghasilkan zona hambat tertinggi yaitu $41 \mathrm{~mm}$ kategori sangat kuat. Pendapat diatas juga diperkuat oleh Davis and Stout (1971), untuk mempermudah dalam menggolongkan kemampuan dari diameter yang diperoleh. Ekstrak dengan diameter hambatan lebih dari $20 \mathrm{~mm}$ termasuk dalam kategori sangat kuat, diameter hambatan berkisar dari 10-20 $\mathrm{mm}$ termasuk dalam kategori kuat, diameter hambatan berkisar dari 5-10 mm termasuk dalam kategori sedang dan diameter hambatan kurang dari $5 \mathrm{~mm}$ termasuk dalam kategori lemah. Zona bening di sekitar cakram kertas merupakan daerah difusi ekstrak yang mempengaruhi pertumbuhan bakteri. Suatu bahan dikatakan mempunyai aktivitas antibakteri apabila diameter hambatan yang terbentuk lebih besar atau sama dengan $6 \mathrm{~mm}$ (Suciati et al., 2012).

Hasil penelitian tersebut juga menunjukkan bahwa semakin besar konsentrasi kombinasi ekstrak Akar Saluang Belum (Lavanga sarmentosa) dengan Akar Kuning (Arcangelisia flava Merr) maka diameter zona hambat yang terbentuk semakin besar. Rerata diameter hambat yang paling tinggi terdapat pada konsentrasi 55 gr/150 ml. Hasil ini memberikan bukti bahwa semakin besar konsentrasi kombinasi ekstrak Akar Saluang Belum (Lavanga sarmentosa) dengan Akar Kuning (Arcangelisia flava Merr) maka zat antibakteri yang dikandung berpengaruh terhadap pertumbuhan bakteri. Lebar diameter zona hambat yang terbentuk disekitar kertas cakram dapat dijadikan sebagai parameter untuk melihat kekuatan senyawa bioaktif yang terkandung di dalam kombinasi Akar Saluang Belum (Lavanga sarmentosa) dengan Akar Kuning (Arcangelisia flava Merr). Semakin lebar diameter zona hambatnya mengindikasikan semakin kuatnya senyawa bioaktif menghambat pertumbuhan bakteri. Suatu bahan antibakteri tertentu aktivitasnya dapat meningkat bila kadar antibakterinya ditingkatkan melebihi kadar hambat minimum (Setiabudy, 2008).

Bahan aktif yang bersifat antibakteri dalam kombinasi ekstrak Akar Saluang Belum (Lavanga sarmentosa) dengan Akar Kuning (Arcangelisia flava Merr) diduga sangat berperan penting dalam menghambat petumbuhan bakteri tersebut, yakni senyawa aktif alkaloid, saponin, terpenoid, dan flavonoid yang terkandung dalam ekstrak akar kuning (Maryani, et.al, 2013), dan senyawa metabolit sekunder saponin dan tannin yang terdapat pada ekstrak akar saluang belum. Adanya senyawa metabolit sekunder alkaloid pada akar kuning menurut Cowan (1999) mengganggu sintesis DNA dan dinding sel. Kemampuan suatu senyawa antimikroba untuk mempengaruhi dinding sel dengan mengharnbat enzirn yang teriibat pada produksi energi dan pembentukan komponen struktural, sehingga pembentukan dinding sel terganggu. Mekanisme kerusakan dinding sel dapat disebabkan oleh adanya akumuiasi komponen lipofilik yang terdapat pada dinding sel atau membran sel, sehingga menyebabkan perubahan komposisi penyusun dinding sel (Nychas dan Tassou, 2000). Dalam keadaan demikian bakteri akan mengalami hambatan pertumbuhan bahkan kematian. Sedangkan adanya senyawa tannin pada akar saluang belum adalah menghambat enzim reverse transkriptase dan DNA topoisomerase sehingga sel bakteri tidak dapat terbentuk (Nuria et al., 2009). Tanin memiliki aktivitas antibakteri yang berhubungan dengan kemampuannya untuk menginaktifkan adhesin sel mikroba, menginaktifkan enzim, dan menggangu transport protein pada lapisan dalam sel (Cowan, 1999). Tanin juga mempunyai target pada polipeptida dinding sel sehingga pembentukan dinding sel menjadi kurang sempurna. Hal ini menyebabkan sel bakteri menjadi lisis karena tekanan osmotik maupun fisik sehingga sel bakteri akan mati (Sari et al., 2011).

Sedangkan senyawa metabolit sekunder saponin yang terdapat pada kedua tanaman yakni Akar Saluang Belum (Lavanga sarmentosa) dengan Akar Kuning (Arcangelisia flava Merr), Mekanisme kerja sebagai 
antibakteri yaitu dapat menyebabkan kebocoran protein dan enzim dari dalam sel (Madduluri et al., 2013). Saponin dapat menjadi anti bakteri karena zat aktif permukaannya mirip detergen, akibatnya saponin akan menurunkan tegangan permukaan dinding sel bakteri dan merusak permebialitas membran. Rusaknya membran sel ini sangat mengganggu kelangsungan hidup bakteri (Harborne, 2006). Saponin berdifusi melalui membran luar dan dinding sel yang rentan kemudian mengikat membran sitoplasma sehingga mengganggu dan mengurangi kestabilan membran sel. Hal ini menyebabkan sitoplasma bocor keluar dari sel yang mengakibatkan kematian sel. Agen antimikroba yang mengganggu membran sitoplasma bersifat bakterisida (Cavalieri et al., 2005).

\section{SIMPULAN}

Kombinasi ekstrak Akar Saluang Belum (Lavanga sarmentosa) dengan Akar Kuning (Arcangelisia flava Merr) memiliki efek antibakteri terhadap bakteri $A$. hydrophila secara in vitro. Konsentrasi efektif Kombinasi ekstrak Akar Saluang Belum (Lavanga sarmentosa) dengan Akar Kuning (Arcangelisia flava Merr) pada konsentrasi $55 \mathrm{gr} / 150 \mathrm{ml}$ dengan diameter zona hambat $15 \mathrm{~mm}$. Perlu dilakukan penelitian lanjutan pada Kombinasi ekstrak Akar Saluang Belum (Lavanga sarmentosa) dengan Akar Kuning (Arcangelisia flava Merr) terhadap bakteri Gram positif dan Gram negatif lainnya, dengan menggunakan bagian lain dari tanaman Akar Saluang Belum (Lavanga sarmentosa) maupun Akar Kuning (Arcangelisia flava Merr). dan penelitian mengenai toksisitas kombinasi ekstrak Akar Saluang Belum (Lavanga sarmentosa) dengan Akar Kuning (Arcangelisia flava Merr). secara in vivo.

\section{DAFTAR PUSTAKA}

Cavalieri, S.J., I.D. Rankin., R.J. Harbeck., R.S. Sautter., Y.S. McCarter., S.E. Sharp., J.H. Ortez., dan C.A. Spiegel. 2005. Manual of Antimicrobial Susceptibility Testing. USA: American Society for Microbiology.

Cowan, M.M. 1999. Plant Products as Antimicrobial Agents. Clinical Microbiology Reviews 12: 564 582. 27.

Davis WW dan Stout TR. 1971. Disc Plate Method of Microbiological Antibiotic Assay. Applied Microbiology. 659- 665.

Harborne, J.B. 2006. Metode Fitokimia: Penuntun Cara Modern Menganalisis Tumbuhan (alih bahasa: Kosasih Padmawinata \& Iwang Soediro). Penerbit ITB: Bandung.

Ikrom, Asih, D.T.R. Wira. R.A., Perkasa, B.B, Rafika, T.N., Wasito, 2014. Studi in vitro ekstrak etanol daun kamboja (Plumeria alba) sebagai anti Aeromonas hydrophila. Jurnal Sains Veteriner 32 (1) : $105-116$
Kordi, K. 2004. Penanggulangan Hama dan Penyakit Ikan. Bina Adiaksara. Jakarta.

Madduluri, Suresh. Rao, K.Babu. Sitaram, B. 2013. In Vitro Evaluation of Antibacterial Activity of Five Indegenous Plants Extract Against Five Bacterial Pathogens of Human. International Journal of Pharmacy and Pharmaceutical Sciences. 5(4): 679-684.

Maryani, Marsoedi, Nursyam, H. 2013. The Phytochemistry and The Anti Bacterial Activity of Yellow Root (Arcangelisia flava Merr.) against Aeromonas hydrophila. Journal of Biology and Life Science 4 (2) : 180 - 190.

Meira, R. 2014. Obat Herbal Tradisional. Universitas Muhammadiyah Semarang : Semarang.

Nuria, Maulita, C., Faizaitun, Arvin, Sumantri, Uji Aktivitas Antibakteri Ekstrak Etanol Daun Jarak Pagar (Jatropha Curcas L) Terhadap Bakteri Staphylococcus Aureus Atcc 25923, Escherichia Coli Atcc 25922, Dan Salmonella Typhi Atcc 1408. 2009. Mediagro. 5(2):26-37.

Nychas, G.J.E. and Tassou, C.C. 2004. Microbiological, Physico-chemical and Organoleptic attributes of a country tomato salad and fate of Salmonella enteritidis during storage under aerobic or modified atmosphere packaging condition at 4 and $10^{\circ} \mathrm{C}$. Food Control 11, 131-135.

Qamariah, N., Handayani, R., Friskila, A. 2018. Uji Daya Hambat Ekstrak Etanol Batang Tumbuhan Saluang Belum Terhadap Bakteri Staphylococcus aureus. Jurnal Surya Medika. Palangka Raya.

Retnawati, P. E. 2008. Pemberian Vaksin Polivalen dengan Chitosan dari Komponen Outer Membran Protein dan Lipopolisakarida Vibrio alginolyticus dan Vibrio anguillarum terhadap Sintasan Benih Kerapu Macan (Epinephelus fuscoguttatus). Tesis Universitas Airlangga. Surabaya.

Rezeky, S., Triyanto, Murwantoko, 2016. Isolasi dan Identifikasi Aeromonas hydrophia dari lele dumbo (Clarias sp.) di Kabupaten Ngawi. Fakultas Pertanian UGM : Yogyakarta.

Sari, F.P. dan S. M. Sari. Ekstraksi Zat Aktif Antimikroba dari Tanaman Yodium (Jatropha multifida Linn) sebgai Bahan Baku Alternatif Antibiotik Alami. 2011. Thesis. Fakultas Teknik Universitas Diponegoro. Semarang.

Setiabudy R. 2008. Antimikroba. In: Tanu I, editor. Farmakologi dan Terapi (5th ed). Jakarta : EGC, p.585.

Suciati A, Wardiyanto, Sumino. 2012. Efektivitas ekstrak daun Rhizopora mueronata dalam menghambat pertumbuhan bakteri Aeromonas salmonicida dan Vibrio harveyi. Jurnal rek. Tekh. budidaya perairan. Vol. 1.

Suryawiria, U. 2005. Mikrobiologi Dasar. Papas Sinar Sinanti. Jakarta. 